\title{
Nasal Methicillin-resistant Staphylococcus aureus Carriage and Related Risk Factors in a University Student Population
}

\author{
Üniversite Öğrenci Popülasyonunda Burunda Metisilin-dirençli Staphylococcus aureus \\ Taşıyıcııı̆̆ ve Illişkili Risk Faktörleri
}

\author{
(1) Gizem ŞANLITÜRK, (1) Babak AHMADKHANPOUR, (1) Seid AL-NUMAN, (1) Seba BETAR, (1) İrem BOZKURT, (1) Komeil HATAMI, \\ (1) Lanya QADIR, (1) Merve UZUN, (1) Mümtaz GÜRAN \\ Eastern Mediterranean University Faculty of Medicine, Department of Medical Microbiology, Cyprus via Mersin 10, Turkey
}

\section{Abstract}

Introduction: Here, we aimed to analyze the risk factors of nasal methicillin-resistant Staphylococcus aureus (MRSA) carriage in a sample pool comprising university students and characterize MRSA isolates' antibiotic resistance profiles.

Materials and Methods: A questionnaire was distributed to each participant and used as a data collection tool for obtaining demographic- and risk factor-related information. Each participant was also screened for S. aureus and MRSA nasal carriage. Associations between MRSA carriage and risk factors were evaluated with biostatistical methods. Bacterial isolates were isolated and identified with standard microbiological techniques. The antibiotic resistance phenotypes of the isolates were analyzed using the disk diffusion method in accordance with the European Committee on Antimicrobial Susceptibility Testing guidelines.

Results: The nasal MRSA carriage rate detected in our population was $11.3 \%$. Having a skin infection in the past year ( $p=0.039$ ) and working in a healthcare system during the previous year $(p=0.018)$ were found to be significant risk factors associated with the nasal MRSA carriage of students. The antibiotic susceptibility test on MRSA isolates demonstrated high resistance rates to rifampicin, erythromycin, and kanamycin.

Conclusion: The high rate (11.3\%) of nasal MRSA carriage among university students is concerning. Thus, activities that aim to enhance knowledge and awareness among university students and administrators should be implemented to prevent possible transmission and outbreak scenarios.

Keywords: MRSA, nasal carriage, risk factor, resistance

Öz

Giriş: Burada, üniversite öğrencilerinden oluşan bir örnek havuzunda metisilin-dirençli Staphylococcus aureus (MRSA) taşıyıcılığı için risk faktörleri analiz edilmesi ve MRSA izolatlarının antibiyotik direnç profillerinin karakterizasyonu amaçlanmıştır.

Gereç ve Yöntem: Risk faktörleri ve demografik bilgilerin elde edilmesi için tüm katılımcılara bir veri toplama aracı olarak anket dağıtılmıştır. Ayrıca, her katılımcı burunda S. aureus ve MRSA taşıyıcılığı için taranmıştır. MRSA taşıyıcılığı ve risk faktörleri arasındaki ilişkiler biyoistatistiksel yöntemlerle değerlendirilmiştir. Bakteriyel izolatların izolasyonunda ve tanımlanmasında standart mikrobiyolojik teknikler kullanılmıştır. İzolatların antibiyotik direnç fenotipleri disk difüzyon metodu ile European Committee on Antimicrobial Susceptibility Testing kriterlerine göre analiz edilmiştir. Bulgular: Popülasyonumuzda burunda MRSA taşıyıcılığı oranı \%11,3 olarak belirlendi. "Geçen yılda bir deri enfeksiyonu geçirmiş olmak" ( $p=0,039$ ) ve "geçmiş yıl içerisinde bir sağlık sisteminde çalışmış olmak" $(p=0,018)$ öğrencilerde burunda MRSA taşıyıcılığı ile ilişkili anlamlı risk faktörleri olarak bulundu. MRSA izolatlarının antibiyotik duyarlılık testi rifampisin, eritromisin ve kanamisin için yüksek direnç oranları ile sonuçlandı.

Sonuç: Üniversite öğrencilerindeki yüksek burunda MRSA taşıyıcılığı oranı $(\% 11,3)$ endişe vericidir. Dolayısı ile, muhtemel yayılma ve salgın senaryolarının önlenmesi için üniversite öğrencilerinde ve yöneticilerinde bilgi ve farkındalığı artırıcı aktiviteler önerilmektedir.

Anahtar Kelimeler: MRSA, burunda taşıyıcılık, risk faktörü, direnç

Cite this article as: Şanlıtürk G, Ahmadkhanpour B, Al-Numan S, Betar S, Bozkurt I, Hatami K, Qadir L, Uzun M, Güran M. Nasal Methicillin-resistant Staphylococcus aureus Carriage and Related Risk Factors in a University Student Population. Mediterr J Infect Microb Antimicrob. 2020;9:2. 


\section{Introduction}

The prevalence of methicillin-resistant Staphylococcus aureus (MRSA) infections is variable among different populations. For vulnerable populations such as patients in intensive care units, MRSA carriage is the most significant predictor of such infections and characteristically more common within hospitals or intensive care units because of increased transmission, high antibiotic usage, and large numbers of vulnerable patients ${ }^{[1,2]}$. For this reason, nasal MRSA carriage is screened continuously in hospital settings, especially in developed countries, to minimize the chance of any possible MRSA infection. However, MRSA spreads throughout a community, and people without any previous hospitalization history can also develop this infection ${ }^{[3,4]}$. As such, MRSA carriage in various populations with different characteristics should be investigated to increase our understanding of MRSA transmission.

The risk factors of MRSA carriage vary among different populations. MRSA carriage is influenced by not only hostrelated factors, such as age, sex, income, and knowledge, but also pathogen-related factors, such as virulence factors, and antibiotic resistance. The effect of risk factors on MRSA carriage can be studied in different populations. For example, university students represent an interesting sample for several reasons. For instance, they represent a group who frequently uses selfmedication; they mostly live in dormitories in a more social environment, which involves more person to-person contact; and they often share equipment such as sports equipment. MRSA carriage among university students is also common with a rate of $7.4 \% 0^{[5]}$.

We still have a limited understanding about antimicrobial resistance in bacteria responsible for a wide range of infections affecting humans residing in Northern Cyprus, a self-governing country located in the northern part of the Cyprus island, which harbors many universities as an international hub for international students. In this study, we aimed to investigate the rate of nasal MRSA carriage among students, its possible association with the risk factors, and the antibiotic susceptibility patterns of MRSA isolates.

\section{Materials and Methods}

\section{Study Design and Population}

A descriptive study was designed to represent a population size of 20,000 students. A sample size of 500 students was calculated (confidence level=95\%, anticipated frequency $=50 \%$ ). Ethical permission to conduct this study was obtained from the university's ethical board (decision number: 2017/40-58), and the study was performed in accordance with the approved guidelines of the Declaration of Helsinki. All participants were recruited voluntarily by conducting nonrandomized convenience sampling and allowed to participate after they signed an informed consent agreement form. Samples were collected between February and May 2018.

\section{Data Collection and Bacterial Isolates}

A questionnaire and bacterial cultures were used for data collection. The standardized questionnaire was taken from a previously published study ${ }^{[5]}$ to assess the risk factors of MRSA carriage. After the necessary permissions were obtained from the authors, the questionnaire was administered to collect the self-reported risk factors that included demographic information, previous infection history, hospital contact, drug/antibiotic use, and living conditions. Nasal swabbing was conducted to collect bacterial samples. In this procedure, sterile swabs moistened with sterile saline water were used to sample both nostrils. The samples were transferred to mannitol salt agar (MSA; BD Diagnostic Systems, Sparks, MD, USA) for $S$. aureus isolation and then to 4\% cefoxitinsupplemented MSA (C-MSA) plates for MRSA isolation. They were subsequently incubated at $37 \pm 1{ }^{\circ} \mathrm{C}$ for $48 \mathrm{~h}$ to isolate MRSA. C-MSA screening method was used to identify MRSA ${ }^{[6]}$. Methicillin-resistance was confirmed with an oxacillin $(1 \mu \mathrm{g})$ disk diffusion test ${ }^{[7]}$. The agars were then screened to determine yellow colonies on C-MSA, and the selected yellow colonies resembling MRSA were transferred to the C-MSA plates for another $24 \mathrm{~h}$ of incubation. The isolates that showed standard microbiological features such as complete hemolysis on blood agar, Gram staining, catalase test, slide and tube coagulase tests, and DNase test, and yellowish growth on C-MSA were confirmed to be MRSA.

\section{Antibiotic Susceptibility Testing}

The antibiotic susceptibility of the collected isolates was analyzed by using the Kirby-Bauer disk diffusion method as recommended by The European Committee on Antimicrobial Susceptibility Testing (EUCAST) guidelines ${ }^{[8]}$. The antibiotics (Oxoid) tested in our study were penicillin (10 U), amoxicillinclavulanic acid $(30 \mu \mathrm{g})$, erythromycin $(15 \mu \mathrm{g})$, vancomycin (30 $\mu \mathrm{g})$, tetracycline $(30 \mu \mathrm{g})$, cefuroxime $(30 \mu \mathrm{g})$, gentamycin (10 $\mu \mathrm{g})$, rifampicin $(5 \mu \mathrm{g})$, and clindamycin $(2 \mu \mathrm{g})$.

The colonies that were grown on C-MSA overnight were added to a sterile physiological saline solution until turbidity reached 0.5 McFarland turbidity standards. Afterwards, the bacteria were inoculated by using a sterile swab into Mueller-Hinton agar (Merck, Germany) and left to dry at room temperature. The selected antibiotic disks were applied, and the plates were incubated at $35 \pm 2{ }^{\circ} \mathrm{C}$ overnight. The zone of inhibition of each antibiotic was measured and interpreted in accordance with the EUCAST guidelines $^{[8]}$. 


\section{Data Analysis}

Data management was performed using Microsoft Excel 2010 software. Statistical analyses were carried out with IBM SPSS version 21 (SPSS Inc., Chicago, IL, USA). The associations between nasal MRSA carriage and risk factors were examined through chi-square analysis. Each variable on the questionnaire was assumed to be an independent variable, and the MRSA carriage outcome was set as the dependent variable. $P$ values obtained via a chi-square $\left(\mathrm{x}^{2}\right)$ test were calculated, and an alpha level of 0.05 was considered to determine the statistical significance of the associations. A file split was performed, and only MRSA-positive questionnaires were re-examined via chisquare analysis.

\section{Results}

A total of 497 students, with a response rate of $99.4 \%$, volunteered to participate in this research. The participants' ages ranged from 17 years to 41 years with a mean age of 20.75 years (standard deviation $=2.26$ ).

The screening of the obtained bacterial samples indicated that 154 and 56 of 497 participants were positive for S. aureus (31\%) and MRSA (11.3\%) nasal carriage, respectively. Among the participants who were screened positive, the mean age was 20.6 years (standard deviation $=1.8$ ), and the male-to-female ratio was 1.67 , with percentages of $63 \%$ to $37 \%$, respectively. Gender and MRSA carriage were not significantly related $(p=0.270)$.

Chi-square analysis showed that "having skin infection, boil, or sore in the past year" $\left(x^{2}=6.588, p=0.037\right)$ and "working in a healthcare facility in the past year" $\left(x^{2}=8.117, p=0.017\right)$ were the significant factors related to nasal MRSA carriage. The distribution of "yes" answers given to questions regarding the risk factors of MRSA carriers and noncarriers is given in Table 1. A file split was performed to investigate the significant associations between the risk factors among the MRSA-positive population, and "yes" answers were analyzed via a chi-square test (Table 2). Among the individuals who were detected to be MRSA (+) and had recently a skin infection, $67 \%$ of the participants were among those who did not have any knowledge about methicillin-resistance or antibiotic resistance. Conversely, 95\% of the MRSA (+) patients that did not have a recent skin infection had no knowledge about MRSA. Furthermore, 70\% of the MRSA (+) participants responding to the question about using antibiotics were hospitalized in the last 12 months. The rate of MRSA (+) participants who responded with yes to the question about their recent skin infection and was hospitalized in the past 12 months was 58\%. Then, 100\% of the MRSA (+) population in the setting of having knowledge about MRSA used antibiotics, and $100 \%$ of the MRSA (+) participants were living longer than 6 months in a dormitory. A rate of $70 \%$ of the MRSA (+) participants having knowledge about MRSA participated in athletics.

The antibiotic susceptibility results of $S$. aureus isolates, MRSA isolates, and methicillin-sensitive S. aureus (MSSA) isolates are given in Table 3. Among all S. aureus isolates, 82\%, 40\%, $36 \%, 36 \%, 27 \%, 18 \%$ and $18 \%$ were resistant to penicillin, tetracycline,cefoxitin, amoxicillin + clavulanic acid, kanamycin, erythromycin, and rifampisin, respectively. The isolates were not resistant to gentamicin, vancomycin, clindamycin, and trimethoprim/sulfamethoxazole. All the MRSA isolates were resistant to penicillin, tetracycline, cefoxitin, and amoxicillin + clavulanic acid. Among 56 MRSA isolates, 42 showed resistance

Table 1. Distribution of "Yes" answers given to questions regarding risk factors by methicillin-resistant Staphylococcus aureus carriers and noncarriers

\begin{tabular}{|c|c|c|c|c|}
\hline & Risk factors & MRSA + & MRSA - & Significance \\
\hline \multirow[t]{3}{*}{ Infections } & Having a skin infection, boil, or sore in the past 12 months & $12(21.4 \%)$ & $13(24 \%)$ & $p=0.039^{*}$ \\
\hline & $\begin{array}{l}\text { Being told by a doctor about having a skin infection called MRSA or } \\
\text { antibiotic-resistant Staphylococcus in the past } 12 \text { months }\end{array}$ & $0(0 \%)$ & $1(2.3 \%)$ & $p=0.66$ \\
\hline & Hearing about MRSA or antibiotic-resistant Staphylococcus & $8(14.3 \%)$ & $9(15.3 \%)$ & $p=0.35$ \\
\hline \multirow{5}{*}{$\begin{array}{l}\text { Healthcare } \\
\text { services }\end{array}$} & Being a patient in a hospital in the past 12 months & $30(53.6 \%)$ & $24(42.4 \%)$ & $p=0.353$ \\
\hline & Having a surgery in the past 12 months & $4(7.1 \%)$ & $5(8.9 \%)$ & $p=0.793$ \\
\hline & Working in a healthcare facility in the past 12 months & $4(7.1 \%)$ & $5(9.3 \%)$ & $p=0.018^{*}$ \\
\hline & Using intravenous drugs in the past 12 months & $11(19.6 \%)$ & $13(23.9 \%)$ & $p=0.753$ \\
\hline & Taking any antibiotics in the past 12 months & $33(58.9 \%)$ & $38(67 \%)$ & $p=0.207$ \\
\hline \multirow{4}{*}{$\begin{array}{l}\text { Living } \\
\text { conditions }\end{array}$} & Currently living in a dorm & $39(69.9 \%)$ & $39(68.9 \%)$ & $p=0.934$ \\
\hline & Living in a dorm in the past 12 months & $36(64.3 \%)$ & $36(63.9 \%)$ & $p=0.948$ \\
\hline & Being in jail in the past 12 months & $2(3.6 \%)$ & $1(1.8 \%)$ & $p=0.605$ \\
\hline & Participating in athletics in the past 12 months & $34(60.7 \%)$ & $31(55.5 \%)$ & $p=0.713$ \\
\hline
\end{tabular}

*Significant association

MRSA: Methicillin-resistant Staphylococcus aureus 
Table 2. Significant associations between different risk factors among the methicillin-resistant Staphylococcus aureus carrier group

\begin{tabular}{l|l}
\hline Associations between riskfactors in the MRSA $(+)$ population $(n=56)$ & Significance $^{* * *}$ \\
\hline $\begin{array}{l}\text { Having a skin infection, boil, or sore in the past } 12 \text { months }(n=12 / 56)^{*} \text { versus hearing about MRSA or antibiotic-resistant } \\
\text { Staphylococcus }(n=4 / 12)^{* *}\end{array}$ & $p=0.008$ \\
\hline $\begin{array}{l}\text { Being a patient in a hospital in the past } 12 \text { months }(n=30 / 56)^{*} \text { versus taking any antibiotics in the past } 12 \text { months } \\
(n=22 / 30)^{* *}\end{array}$ & $p=0.019$ \\
\hline $\begin{array}{l}\text { Taking any antibiotics in the past } 12 \text { months }(n=33 / 56)^{*} \text { versus hearing about MRSA or antibiotic-resistant Staphylococcus } \\
(n=8 / 33)^{* *}\end{array}$ & $p=0.039$ \\
\hline $\begin{array}{l}\text { Hearing about MRSA or antibiotic-resistant Staphylococcus }(n=34 / 56)^{*} \text { versus participating in athletics in the past } 12 \\
\text { months }(n=2 / 34)^{* *}\end{array}$ & $p=0.012$ \\
\hline
\end{tabular}

${ }^{*}$ Frequency of participants having the mentioned risk factor within MRSA carriers.

${ }^{*}$ Frequency of participants having the mentioned risk factor within the compared risk factor.

${ }^{* * *} P$ values from the chi-square test that shows significant associations between relevant risk factors.

MRSA: Methicillin-resistant Staphylococcus aureus

Table 3. Antibiotic susceptibility results of study isolates

\begin{tabular}{|c|c|c|c|c|c|c|c|c|c|c|c|c|}
\hline \multirow[t]{2}{*}{ Antibiotics tested } & \multicolumn{4}{|c|}{ Totala } & \multicolumn{4}{|c|}{ MRSA $^{b}$} & \multicolumn{4}{|c|}{ MSSAc } \\
\hline & $S$ & $\mathbf{R}$ & I & $\mathrm{R} \%$ & S & $\mathbf{R}$ & I & $\mathrm{R} \%$ & $S$ & $\mathbf{R}$ & I & $\mathrm{R} \%$ \\
\hline Penicillin & 23 & 126 & 5 & 82 & 0 & 56 & 0 & 100 & 23 & 70 & 5 & 71 \\
\hline Cefoxitin & 98 & 56 & 0 & 36 & 0 & 56 & 0 & 100 & 98 & 0 & 0 & 0 \\
\hline Amoxicillin + clavulanic acid & 98 & 56 & 0 & 36 & 0 & 56 & 0 & 100 & 98 & 0 & 0 & 0 \\
\hline Rifampicin & 126 & 28 & 0 & 18 & 28 & 28 & 0 & 50 & 98 & 0 & 0 & 0 \\
\hline Gentamicin & 140 & 0 & 14 & 0 & 42 & 0 & 14 & 0 & 98 & 0 & 0 & 0 \\
\hline Vancomycin & 154 & 0 & 0 & 0 & 56 & 0 & 0 & 0 & 98 & 0 & 0 & 0 \\
\hline Clindamycin & 140 & 0 & 14 & 0 & 42 & 0 & 14 & 0 & 98 & 0 & 0 & 0 \\
\hline
\end{tabular}

aAll the isolated Staphylococcus aureus samples, bindividual MRSA samples, cindividual MSSA samples.

S: Susceptible, R: Resistant, I: Intermediately resistant, MRSA: Methicillin-resistant Staphylococcus aureus, MSSA: Methicillin-sensitive S. aureus

to kanamycin. Half of the isolates were resistant to erythromycin and rifampisin.

\section{Discussion}

Many significant risk factors associated with nasal MRSA carriage are recognized. However, risk factors may vary between different populations with unique characteristics. In this crosssectional study, the nasal carriage rates of MRSA in a sample pool comprising university students were evaluated, and the risk factors associated with this population were analyzed. The bacterial isolates were analyzed for antibiotic susceptibility patterns. As a result, the nasal MRSA carriage rate was $11.3 \%$ in our population.

Country-specific variations, hospital contact, exposure to risk factors, and differences in population structures are the most influential factors determining the MRSA carriage rates.
Geographically, nasal MRSA carriage rates tend to be lower in developed countries, such as those in the Scandinavian region, and higher in less-developed countries, especially in some parts in Asia and America ${ }^{[9]}$. In Turkey, community-associated MRSA rates are reported to be within $21 \%-25 \%{ }^{[10]}$. Interestingly, specific populations such as prisoners, homeless people, sports teams, and nurses have different nasal MRSA carriage rates ${ }^{[11-15]}$. In our population of university students, which belongs to different nationalities, the nasal $S$. aureus carriage rate was $30.9 \%$, and the MRSA carriage rate was $11.3 \%$. S. aureus nasal carriage rates remarkably vary among different populations; however, our rates are comparable with other reports with similar study samples ${ }^{[16-18]}$. Studies focusing on university students have reported MRSA prevalence in a range between $1.5 \%$ and $13 \%{ }^{[18-22]}$. Most studies have investigated medical students, which are characteristically a narrower population with low MRSA carriage rates ${ }^{[18,19]}$. In our sample pool, the 
MRSA carriage rate is much lower in contrast to rates reported for general community as students represent a younger and healthier population. This study demonstrated that the MRSA carriage rates were higher than those of studies that focused on medical students but similar to the rates provided in studies with a mixed student population profile. This result could be related to poor medical knowledge when the sample pool was widened to cover nonmedical students.

The following risk factors regarding nasal MRSA carriage are well defined: typically being healthcare associated, being admitted to a hospital, being an intravenous drug user, and being a man having sex with men ${ }^{[16,23]}$. In the present study, we used a data collection tool specifically designed to investigate the risk factors that could be associated with students' life. Our results suggested that only "having a skin infection in the past" and "working in a healthcare system during the previous year" as significant risk factors of nasal MRSA carriage among students. Having a skin infection has been reported as a significant risk factor for various populations including healthy people previously ${ }^{[3]}$. Conversely, the significant relationship between the MRSA carriage and risk factor of "working in a healthcare system in the previous year" might rise a question about the MRSA-related infection risk of students having additional work in healthcare facilities. However, this study did not confirm a variety of other previously identified risk factors of nasal MRSA carriage possibly because most of the commonly known risk factors were identified in clinical populations and medical students but not in a healthy and general university population. Likewise, studies focusing on a general university population showed no significant associations with MRSA carriage and commonly known risk factors such as gender, recent antibiotic use, or prior infections ${ }^{[5,24]}$.

The antibiotic susceptibility results of MRSA isolates from the present study demonstrated high resistance rates to antibiotics that are thought to be a therapeutic option for treating MRSA infections.The tested antibiotics and the resistance rates of MRSA isolates were penicillin (100\%), tetracycline $(100 \%)$, cefoxitin $(100 \%)$, amoxicillin + clavulanic acid $(100 \%)$, kanamycin (75\%), erythromycin (50\%), and rifampicin (50\%). No isolates were resistant to gentamicin, vancomycin, clindamycin, and trimethoprim/sulfamethoxazole. Previous studies with similar sample populations reported increased resistance rates of MRSA isolates to erythromycin, tetracycline ${ }^{[5,25,26]}$. However, resistance to rifampicin and kanamycin is observed in clinical MRSA isolates mostly isolated from hospitalized patients ${ }^{[27,28]}$. The reason may be the excessive use of such antibiotics in our sample population because they are still easily accessible in our country. Other last-resort antibiotic groups, including clindamycin, trimethoprim/sulfamethoxazole, vancomycin, and gentamycin,which should be saved for severe cases, were found to be effective against MRSA isolates. These results highlighted the need to formulate more strategies for the rational use of antibiotics.

Several limitations should be noted about the current work. (i) Sampling was not randomized, and our study design was unable to allow the decolonization of MRSA carriers, distinguish between the persistent and temporary colonization of nasal carriage, and evaluate differences between medical and nonmedical students. (ii) Students constituting the sample pool might have been lacking knowledge to accurately complete the questionnaire. (iii) The lack of molecular identification methodologies could have led to inaccuracies in the specieslevel definition of isolates.

\section{Conclusion}

This study showed that being a university student may be associated with nasal MRSA colonization, and "having a skin infection in the past" and "working in a healthcare system during the previous year" are significant risk factors associated with the nasal MRSA carriage among university students. Susceptibility profiles demonstrate that MRSA isolates among this population remain susceptible to common first-choice antibiotics for MRSA with remarkable resistance rates to kanamycin, erythromycin, and rifampicin.

University administrators should be aware of the potential transmission risks and outbreak scenarios that can develop within a student's life. Thus, activities that aim to enhance knowledge and awareness among this population should be suggested.

\section{Acknowledgments}

The data presented in this manuscript are collected by an undergraduate student group through Introduction to Clinical Skills-2 Research program of our faculty.

\section{Ethics}

Ethics Committee Approval: The study were approved by the Eastern Mediterranean University University of Local Ethics Committee (decision number: 2017/40-58).

Informed Consent: All participants were recruited voluntarily by conducting nonrandomized convenience sampling and allowed to participate after they signed an informed consent agreement form.

Peer-review: Externally and internally peer-reviewed.

\section{Authorship Contributions}

Concept: M.G., Design: M.G., Data Collection or Processing: B.A., S.N., S.B., I.B., K.H., L.O., M.U., G.Ş., Analysis or Interpretation: M.G., B.A., S.N., S.B., I.B., K.H., L.Q., M.U., G.Ş., 
Literature Search: M.G., G.Ş., B.A., S.N., S.B., I.B., K.H., L.Q., M.U., Writing: M.G., G.Ş.

Conflict of Interest: No conflict of interest was declared by the authors.

Financial Disclosure: The authors declared that this study received no financial support.

\section{References}

1. McGowan JEJ, Tenover FC. Confronting bacterial resistance in healthcare settings: a crucial role for microbiologists. Nat Rev Microbiol. 2004;2:251-8.

2. Gould IM. The clinical significance of methicillin-resistant Staphylococcus aureus. J Hosp Infect. 2005;61:277-82.

3. Pan $\mathrm{HH}$, Huang $\mathrm{YC}$, Chen $\mathrm{CJ}$, Huang $\mathrm{FL}$, Ting PJ, Huang JY, Chiu $\mathrm{CH}$, Lin TY, Chen PY. Prevalence of and risk factors for nasal methicillin-resistant Staphylococcus aureus colonization among children in central Taiwan. J Microbiol Immunol Infect. 2017;52:45-53.

4. Kim MW, Greenfield BK, Snyder RE, Steinmaus CM, Riley LW. The association between community-associated Staphylococcus aureus colonization and disease: a meta-analysis. BMC Infect Dis. 2018;18:86.

5. Rohde RE, Denham R, Brannon A. Methicillin resistant Staphylococcus aureus: carriage rates and characterization of students in a Texas university. Clin Lab Sci. 2009;22:176-84.

6. Smyth RW, Kahlmeter G. Mannitol salt agar-cefoxitin combination as a screening medium for methicillin-resistant Staphylococcus aureus. J Clin Microbiol. 2005;43:3797-9.

7. Jayaratne $P$, Rutherford C. Detection of methicillin-resistant Staphylococcus aureus (MRSA) from growth on mannitol salt oxacillin agar using PCR for nosocomial surveillance. Diagn Microbiol Infect Dis. 1999;35:13-8.

8. EUCAST. European Committee on Antimicrobial Susceptibility Testing Breakpoint tables for interpretation of MICs and zone diameters. Eur Comm Antimicrob Susceptibility Testing Break tables Interpret MICs Zo diameters Version 80, 2018 2015:1-77. Available from: https://eucast.org/

9. Lee AS, Lencastre H De, Garau J, Kluytmans J, Malhotra-kumar S, Peschel A, Harbarth S. Methicillin-resistant Staphylococcus aureus. Nat Publ Gr. 2018:4:1-23.

10. The Center for Disease Dynamics Economics \& Policy. ResistanceMap: Antibiotic use [Internet]. 2018. Available from: https://resistancemap. cddep.org/AntibioticUse.php

11. El Aila NA, Al Laham NA, Ayesh BM. Nasal carriage of methicillin resistant Staphylococcus aureus among health care workers at Al Shifa hospital in Gaza Strip. BMC Infect Dis. 2017;17:1-7.

12. David MZ, Siegel JD, Henderson J, Leos G, Lo K, Iwuora J, Taylor AR, Zychowski DL, Porsa E, Boyle-vavra S, Daum S. Hand and nasal carriage of discordant Staphylococcus aureus isolates among urban jail detainees. J Clin Microbiol. 2014;52:3422-5.

13. Schubert M, Kampf D, Jatzwauk L, Kynast F, Stein A, Strasser R, Dulon M, Nienhaus A, Seidler A. Prevalence and predictors of MRSA carriage among employees in a non-outbreak setting: a cross-sectional study in an acute care hospital. J Occup Med Toxicol. 2019;14:7.

14. Leibler JH, Leon C, Cardoso LP, Morris JC, Miller NS, Nguyen DD, Gaeta JM. Prevalence and risk factors for MRSA nasal colonization among persons experiencing homelessness in Boston, MA. J Med Microbiol. 2017;66:11838.

15. Couve-Deacon E, Postil D, Barraud O, Duchiron C, Chainier D, Labrunie A, Pestourie N, Preux PM, Francois B, Ploy MC. Staphylococcus aureus carriage in french athletes at risk of CA-MRSA infection: a prospective, crosssectional study. Sports Med Open. 2017;3:28

16. Mehraj J, Witte W, Akmatov MK, Layer F, Werner G, Krause G. Epidemiology of Staphylococcus aureus nasal carriage patterns in the community. Curr Top Microbiol Immunol. 2016;398:55-87.

17. Laub K, Tothpal A, Kovacs E, Sahin-Toth J, Horvath A, Kardos S, Dobay 0 . High prevalence of Staphylococcus aureus nasal carriage among children in Szolnok, Hungary. Acta Microbiol Immunol Hung. 2018;65:59-72.

18. Okamo B, Moremi N, Seni J, Mirambo MM, Kidenya BR, Mshana SE. Prevalence and antimicrobial susceptibility profiles of Staphylococcus aureus nasal carriage among pre-clinical and clinical medical students in a Tanzanian University. BMC Res Notes. 2016;9:47.

19. Efa F, Alemu Y, Beyene G, Gudina EK, Kebede W. Methicillin-resistant Staphylococcus aureus carriage among medical students of Jimma University, Southwest Ethiopia. Heliyon. 2019;5:e01191.

20. Demirel G, Findik D, Dagi HT, Arslan U. Community-acquired methicillinresistant Staphylococcus aureus and genotypes among university students in Turkey. Southeast Asian J Trop Med Public Health. 2014;45:1401-9.

21. Abroo S, Hosseini Jazani N, Sharifi Y. Methicillin-resistant Staphylococcus aureus nasal carriage between healthy students of medical and nonmedical universities. Am J Infect Control. 2017:45:709-12.

22. Orlin I, Rokney A, Onn A, Glikman D, Peretz A. Hospital clones of methicillinresistant Staphylococcus aureus are carried by medical students even before healthcare exposure. Antimicrob Resist Infect Control. 2017;6:15.

23. Kale $P$, Dhawan $B$. The changing face of community-acquired methicillinresistant Staphylococcus aureus. Indian J Med Microbiol. 2016;34:275-85.

24. Morita JE, Fujioka RS, Tice AD, Berestecky J, Sato D, Seifried SE, Katz AR. Survey of methicillin-resistant Staphylococcus aureus (MRSA) carriage in healthy college students, Hawai'i. Hawaii Med J. 2007;66:213-5.

25. Rackham DM, Ray SM, Franks AS, Bielak KM, Pinn TM. CommunityAssociated Methicillin-Resistant Staphylococcus aureus Nasal Carriage in a College Student Athlete Population. Clin J Sport Med. 2010;20:185-8.

26. Chen BJ, Xie XY, Ni D, Dai XL, Lu Y, Wu XQ, Li HY, Yao YD, Huang SY. Factors associated with Staphylococcus aureus nasal carriage and molecular characteristics among the general population at a Medical College Campus in Guangzhou, Ann Clin Microbiol Antimicrob. 2017;16:28.

27. Bongiorno D, Mongelli G, Stefani S, Campanile F. Burden of Rifampicin- and Methicillin-Resistant Staphylococcus aureus in Italy. Microb Drug Resist. 2018;24:732-8.

28. Murugan K, Kavitha K, Al-Sohaibani S. Rifampicin resistance among multiresistant MRSA clinical isolates from Chennai, India, and their molecular characterization. Genet Mol Res. 2015;14:2716-25. 